\title{
Dánél Mónika
}

\section{On the Poetics of Hungarian Neo-Avantgarde Texts}

Within the trichotomical context of the classical modernity, avantgarde and postmodernity the experience of the fact that the postmodern paradigm is preceded by the neo-avantgarde paradigm that - as it seems to us at the time being - takes on from the avantgarde techniques, but at the same time also differs from it, mainly in the way it faces tradition in an affirmative way, being simultaneously a premise of the formation of the postmodernist aesthetics and way of quoting.

The paper attempts at characterizing the neoavantgarde poetics through the chosen textual samples. Along Fehérlófia I-VI. by Géfin László Kemenes I pinpoint at the interrelation of the genres, the simultaneity of the different styles and discourses - issues that thematise and problematise the possibilities of the narration. There isn't possible a global, coherent grand narrative, but by means of the different genres (the tale, the epic poem, the autobiography, the tragedy) its memory seems to be preserved. The major poetic characteristics of the avantgarde can be perceived in such dichotomies.

When interpreting the prose poem entitled A fényképésznél by György Vitéz I underline the possibilities that occur as the consequences of the simultaneity of the different genres and literary forms. The approaches introduce a category that I, for one, consider extremely proper and characterising regarding the neo-avantgarde poetics. The in-between character could be defined as consisting not only in the simultaneous state of the differences, but in their relatedness, i. e. act upon one another. This phenomenon can be well-perceived at the level of the genres, languages, allusions. The paper tried to improve its conception within the context of the notion of the rhizome (DeleuzeGuattari).

\section{A közöttiség alakzatai. Magyar neoavantgárd szövegek poétikájáról}

\section{Bevezető}

Mai irodalomértésünk meghatározója az intertextuális olvasás, azazhogy a szövegeket nem elszigetelten, hanem más szövegek viszonyában értelmezzük. Az intertextualitás mint olvasási „alakzat” irodalomtörténet-értésünket is nyilvánvalóan módosítja. Az intertextuális emlékezet révén a szövegek olyan viszonyhálózatban képzelhetők el, amelynek létmódja folytonos átrendeződés, átértékelés. Így a történeti rögzítésben érdekelt irodalomtörténet-írás saját illuzórikus voltára kell hogy reflektáljon, hiszen a szövegek hatástörténetük révén olyan jövőbeli kontextusba íródnak bele, amelyről csak előfeltételezések lehetségesek.

A kilencvenes évek „legújabb” magyar irodalma (itt fóként Garaczi László szövegeire gondolok) olyan poétikát hozott létre, amely egyrészt olvasói tanácstalanságot váltott ki, másfelöl - ahogyan azt Bónus Tibor és Kulcsár-Szabó Zoltán alapos elemezései megmutatták e szövegek recepcióját is az inadekvát olvasói elvárások határozták meg. Mindez talán azért volt lehetséges, mert a Garaczi-próza még az Esterházy-szövegek által kialakított elváráshorizontokat sem hagyta teljes mértékben érvényesülni. (Ugyanakkor az Esterházyhagyomány olyan aspektusait emelte ki, olvasta újra, amelyeket a maguk idejében szintén félreolvastak.) Például a szerzői név „szövegiesülése” a Mintha élnélben a Termelési regény E. P.-(j)ének termékeny kontextusává válik.)

Úgy gondolom, hogy a Garaczi szövegek poétikája egy olyan hagyománnyal is kapcsolatot teremt, amely - irodalmon kívüli okok miatt - kimaradt a magyar irodalomtörténetböl, irodalomértésből. Ebben az összefüggésben főként a neoavantgárdra gondolhatunk, kiemelten Kemenes Géfin László poétikájának és retorikájának sajátosságaira. Az intertextuális 
kapcsolódások révén nem csupán a két szövegkorpusz újraolvasása történhet meg, hanem jelentős irodalomtörténeti hozadéka is lehet, amennyiben e sajátosságok hangsúlyozásakor árnyaltabbá válhat a „,neoavantgárd” és a „posztmodern” közötti különbség. Kapcsolódás figyelhető meg a Mintha élnél és a Fehérlófia I-VI. között például a mese architextusának kitüntetett szereptulajdonításában, mely mindkét szöveg esetében a müvek reális-irreális oppozíció mentén való értelmezésének elbizonytalanítását eredményezi, létrehozva ezzel egyben az önéletírás müfajának átértelmezését is. Ugyanígy a szövegek szervezödésének módjaként értett montázstechnika is a kapcsolhatóságokra enged következtetni.

Természetesen szembesülnünk kell magyar vonatkozásban a neoavantgárd elnevezés megalapozatlanságával. Szabolcsi Miklós az izmusok sorozatban megjelent Neoavantgarde előszavában magyarokról tulajdonképpen nem is beszél, ugyanakkor Béládi Miklós $A$ vizuális költészet vagy a költői újítás határai címü tanulmányában elismerően szól a párizsi Magyar Mühely köré szerveződő írók szövegeiről. És itt akkor jogosan merül fel a kérdés, hogy beszélhetünk-e egyáltalán valamilyen átfogó „irányzatról”, amelyet neoavantgárdnak nevezhetnénk. Erre egyfajta válaszlehetőséget kínálhat Kemenes Géfin László szövegeinek vizsgálata.

Szintén fokozott mértékben kell feltárni és figyelembe venni a történeti avantgárdhoz való viszonyát. „A neoavantgárd intézményesíti az avantgárdot mint müvészetet, és ezzel megszünteti az eredeti avantgardista szándékot.” - írja Peter Bürger. ${ }^{280}$ Vagyis a neoavantgárd mint ismétlés történetivé teszi az avantgárdot, és az ismétlés révén megfosztja egyszeriségétől, szingularitásától. Ezzel ugyanakkor az avantgárd azon törekvése is lelepleződik, hogy olvasat és mü egyesíthetők lennének, hiszen az olvasás eleve mint (nem identikus) ismétlés fogható fel. Ugyanakkor a halandzsa nyelv eszményének illuzórikusságára is felhívják az avantgárd újraértelmezői a figyelmet, immáron a nyelv jelentésteremtő potenciálját emelve ki. A neoavantgárd már nem törekszik a nyelvi jelentések kiüresítésére, hanem a mégoly gépies „számítógépes irodalom” is azt bizonyítja, hogy a nyelvi jel „mindig már potenciális jelentések egyfajta emlékmüve". ${ }^{281}$

Kemenes Géfin László szövegeinek értelmezése során véleményem szerint a magyar neoavantgárd egyik jelentős aspektusa tárulhat fel, egyúttal a Garaczi-próza mint egy lehetséges újraolvasás már eleve egy hatástörténeti horizontban (is) interpretáltatja e szövegeket. Ily módon valóban a hatástörténet révén létrejövő intertextuális kapcsolódás teszi lehetetlenné az elszigetelő értelmezési kísérleteket, és ezáltal még inkább hangsúlyossá válik a Kemenes szövegek erős kötődése a különböző nyelvi hagyományokhoz.

Dolgozatomban a választott szövegek értelmezésével néhány neoavantgárdra jellemző sajátosságot szeretnék hangsúlyozni. A Fehérlófia kapcsán elsősorban a müfajok egymásra hatását, a különböző stílusok, diskurzusok egyidejüségét emelem ki, mint amely aspektusok az elbeszélhetőséget problematizálják. Már nem lehetséges egységes, koherens „nagy elbeszélés", ugyanakkor a különböző müfajok révén (mese, eposz, önéletrajz, tragédia) megőrződik az emlékezete. És ebben a kettősségben ragadható meg a neoavantgárd legfőbb poétikai vonása. Szintén ilyen kettős viszonyulás figyelhető meg az elbeszélői én szerepét illetően is, mivel itt is a „nagy hős” kontúrjai ugyancsak meglelhetők (táltos, garabonciás, bildungs subject, tragikus hős), viszont ezekhez maszkosító, arcrongáló komponensek társulnak. Ezt a sajátosságát a könyvnek főként a szerzői név szövegiesülése kapcsán vizsgálom.

${ }^{280}$ Peter BÜRGER: Az avantgarde müalkotás. = Széplitaratúrai ajándék. 1997/3-4., 7.

281 KULCSÁR-SZABÓ Zoltán: Az idegenség poétikája? = Újraolvasó. Tanulmányok Kassák Lajosról. (Szerk. Kabdebó Lóránt, Kulcsár Szabó Ernő, Kulcsár-Szabó Zoltán, Menyhért Anna), Anonymus, 2000. 56. 
Ez azért is kap kiemelt szerepet, mert a Garaczi teremtette hatástörténet ezt a sajátosságát is tovább értelmezi e hagyománynak.

Vitéz György, szintén nyugaton élő költőnek A fényképésznél címü „prózaverse” kapcsán ugyancsak a műfajok és münemek egyidejüségből adódó eltérő értelmezési lehetőségeket villantom fel, ugyanakkor ebben a széttartó, szétszóródó szövegáramlásban arra próbálok rákérdezni, hogy az intertextualitás, mint ami a posztmodern irodalomban a szövegek létmódjává vált, szükségszerüen funkcionális kell-e hogy legyen, és ez valamilyenfajta értelemképzésre ad-e lehetőséget, vagy csupán a szövegek egymásmelletiségét, kaotikusságát akarja hangsúlyozni, és akkor ebben az esetben pontosan az a funkciója az intertextualitásnak, hogy ellehetetlenítse az értelemképzést. A „bazári” jelleg felerősítésével a célelvü interpretációt kérdőjelezi meg. A szöveg ezen a ponton olyan kérdéseket vet fel, amelyek mentén elég nehézzé válik a neoavantgárd és posztmodern elkülönítése. Hiszen a szövegben az intertextualitás révén olyan poétika van jelen, amely már a posztmodern esztétika sajátja. Azonban az elbeszélői hanghoz olyan autoritás társul, amely mindvégig megőrzi az én integritását. Ebben a neoavantgárd poétikában tehát, a szöveghatárok feloldódásával nem jár együtt az én-határok feloldódása.

\section{Fragmentaritás és egészelvüség. Müfajok kollázsa}

Kemenes Géfin László Fehérlófia I-VI. címü 1991-ben megjelent könyve a magyar neoavantgárd reprezentatív alkotása. Számos müfajt megidéz, azonban mindannyit át is értelmezi, hiszen ahogyan egymással viszonyba kerülnek egy szövegen belül az egyidejüség révén, kiiktathatatlan az egymásra gyakorolt hatásuk. A könyv már annak tudatát mutatja, hogy az „elbeszélő funkció elveszíti müködtetőit: a nagy hőst, a nagy veszélyeket, a nagy utazásokat és a nagy célt. Szétoszlik az elbeszélő és egyben denotatív, előíró, leíró stb. nyelvelemek felhőiben, ahol minden elem a maga gyakorlati sui generis vegyértékével mozog."282 Azonban ezek a sajátosságok mégis megjelennek a könyvben, csakhogy már mint emlékezet, hiány, úgy mint ami már nem jöhet létre, esetleg csak töredékei mutathatók meg. Ebböl fakadhat az olyanfajta kettősség, amelyet úgy határozhatunk meg, hogy töredékes nagy elbeszélés. A széttartó műfajok külön-külön egy-egy elbeszélésformát jelentenének, csakhogy szimultán megjelenésük dekonstruálódásukat hozza létre. Ezért beszélhetünk müfajok kollázsáról a szöveg esetében, abban az értelemben, ahogyan Peter Bürger meghatározza: ,a kollázs ugyan lehetővé teszi egy konstrukciós elv felismerését, de a jelentés egységének értelmében vett szintézisét semmiképpen". ${ }^{283}$

Amint azt a címe is jelzi, a mese architextusát idézi meg. Fehérlófia a mesében ${ }^{284}$ egy fehér lónak a fia, aki a táltoshoz hasonlóan, miután kiállja az alvilág próbáit, boldogan él a legkisebb királykisasszonnyal, míg meg nem hal. Látható, hogy ez egy „nagy elbeszélés”, egy „nagy hős” pretextusát képezi meg. Kemenes könyvében a kezdés és a befejezés megőrzi a mese keretét, születéssel kezdődik és Krisztinával való harmonikus együttlét zárja a szöveget. Azonban azt a fejlödéselvü linearitást, amely a mesét jellemzi, itt alineáris, töredékes szerveződés helyettesíti. A könyvbeli utolsó jelenet csupán egy gyerekkori emlék felidézése, és nem egy bildungs-történet kiteljesedő befejeződése. Az azonban, hogy ez a jelenet kerül a szöveg végére, mégis felidézi a mese szerkezetét, s annak mint koherens elbeszélésnek a müfaji jelölőit ezáltal részben megtartja. A könyvben a mese elemei elszórva jelennek meg, és

\footnotetext{
282 Jean-François LYOTARD: $i . m .8$.

${ }^{283}$ Peter BÜRGER: $i$. $m .21$.

${ }^{284}$ Fehérlófia. ARANY László feldolgozása. = Ezer Esztendő. Millenniumi olvasókönyv, Budapest, 2000. 18-24.
} 
oly sok más elemmel, müfajjal, stílussal keverednek, hogy lehetetlen egységgé olvasni. Bármennyire is kiemelt szerepet kap a mese a könyvben a cím és az említett keret miatt, mégis csupán egy múfaj a többi megidézett közül, és bizonyos aspektusai vannak jelen másokkal kombinálódva. Már a kezdésben a születés (illetve csak az „őslóból” lehet erre következtetni) mitikus jelenete keresztény nyelvi hagyománnyal kacsolódik össze, az Ómagyar Mária-siralomból vannak idézetek bevágva, ugyanakkor Ádám és Éva is jelen van.

Melaszos éj bakacsinja alatt kukoricagoréban Éva s Ádám ölelkezik remeg a meztelen hímárbóc nyikorog vad csörtet vadak csörtetése vadak borostás szeme világít a határkő túl a szögesdrót taraján

Egyszerủ eső esik, nem a kozmosz antropomorf könnye istálló trágyás melegébe bújnak megszegi az utolsó kenőmájast leheletük leszáll a jászolra

ahol vértől iszamos szénában jaj én édes fiadom nyugszik a felismerhetetlen kisded s akkor

a gazda eltolja a sziklakövet (...) erdő mélyén egy nagy tóban ösemberek lubickolnak órjás tenyerük nagyot csattan a mézillatú alkonyatban szőrös hátuk duzzadt mellek zónái a szerelemnek a tüzföld is feljön az égre míg elhal az ősök röfögése fehér ősmag gyürüz a vízben fehér öshab csap ki a partra fehér ösmadár dalbafogna fehér ősló elbotlik zokogásában patanyomok glóriája süppedő tőzegen

Mert nála senki sem fehérebb

Izzóbb dicsfény senki homlokát nem övezi $\mathrm{s}$ amikor az illatos vadon vad öszbe fordul amikor recsegö lemezbe gyürödik az erdei tó

ő a szenet egyedül lapátolja: Ó én édes fiam egyetlen magzatom, hogyan is tudtál elhagyni engemet ${ }^{285}$

Krisztus születésének jelképei is megjelennek (istálló, jászol), ugyanakkor ezek egyszerre tartozhatnak a Fehérlófia születéséhez is, hiszen ló szüli meg. A születéshez, eredethez kapcsolódó „elbeszélések” kombinációja jön létre. A fehér szín nemcsak az ismétlés révén van kiemelve, hanem a szöveg tipográfiai elrendezése is feltünővé teszi. „A fehér az isteni fényt, a tökéletességet, a tisztaságot és az ártatlanságot szimbolizálja. (...) A magyar népköltészet színszimbolikájában a fehér szín minden esetben a megtisztulást, az ártatlanságot és a szüzességet jelzi. Alkalmas az ártó erők távol tartására, s így válhatott gyászínné is." - áll a Jelképtárban. ${ }^{286}$ Itt mindezek a jelentések a kezdettel, az őseredetivel kapcsolódnak össze. Ugyanakkor a fehér sugallta tisztaságképzetet azért is érdemes kiemelni, mivel a szöveg a továbbiakban nyelvileg is ezt szeretné megvalósítani, a különböző nyelvi hagyományokat, a konvencionálissá, megszokottá vált szókapcsolatokat szokatlanná, újszerüvé írja át, de ezt oly módon teszi, hogy egyben fel is idézi annak emlékezetét. Csak néhány példa: „kigulágos

${ }^{285}$ Fehérlófia. 7, 8.

${ }^{286}$ Jelképtár. (Szerk. Hoppál Mihály, Jankovics Marcell, Nagy András, Szemadám György) Második javított kiadás, Helikon, Budapest, é. n., 206. 
kiguwattig”, „Te lehetsz - írja Schebemneck - gyöngy, ürü, kés túl pinán”, „hiába habzanak rántástól vakolásig”, „ránc ránc Dnyeszter-ránc, Eszterházy-cérna”. A szövegben ez így tematizálódik: „make it new újítsd meg a nyelvet, abból ismernek meg”. Ez a nyelvújító „magatartás” nyelvkritikusi attitüddel társul ${ }^{287}$, ahogyan arról Margócsy ír a hetvenes évek magyar lírája - bár ő csak a magyarországiakat veszi figyelembe - ebben hoz újat a magyar líraértésben. A nyelvre való odafigyelés nem a klasszikus modern esztétizmusát eredményezi, hanem egy ironikus, demisztifikáló, kifejezés határaira reflektáló nyelvhasználatot. Ugyanakkor a költészet már nem mint egy elkülönített „magas” nyelvi világ létezik, hanem benne szétválaszthatatlanná válik az irodalmi és (a korábban) nem irodalmi regiszter. Kemenes szövegében egyenesen köznyelvi szófordulatok „litániája” („káromlás a nyelved absztrakt litánia") olvasható, és az sem véletlen, hogy a fent idézett metatextusként is interpretálható ,úuítsd meg a nyelvet...” kijelentés után következik az egymásból tovább gördülő felsorolás.

nyista meredek sóder, ne hamukálj, mit gurítasz

csak nem engem akarsz lelejmolni átvered ám a jóanyádat

csanázod a roma vakerát? te akarsz engem megfúrni hazavágni

átrázni átdobni átejteni átvágni? te fütöd az én agyamat,

te akarod megdönteni a dumámat megfújni megbugázni?

mit gondolsz ürge vagyok és csak úgy megeszem a körmös halat?

megkajolom a süket dumádat kinek nyomod te a szöveget

mit habzol itt bazmeg mit vered a rikácsot bazmeg

ennek már lőttek édesapám jobb ha lekopsz kilősz olajra lépsz

elhúzod a csíkot hazakíséred magad eltünsz a balfenéken

hiába rázod a rongyot

hiába rúzsozod azt a kinyiffant jó kurva anyádat

ennek a bulinak löttek alma a fa alatt nyári piros alma

haggyuk ibolyka elég a hamukából söprés a picsába értem?

leléptettem... ${ }^{288}$

Olyan sajátos poétikát eredményez, amelynek nyelve nem egy elzárt, elkülönített esztétikai „szférában” van adva, hanem önmaga hozza létre azokat a különböző nyelvi regiszterekből,

${ }^{287}$ Margócsy István a hetvenes évek lírájáról írott szövegét találónak tartom ebben a kontextusban. Vö. „Poétikailag vizsgálva, már e költészetek jellemzöit, döntő érvként a nyelvvel szemben tanúsított kritikai attitűd kibomlását hozhatnánk fel. Bár korántsem kívánjuk e költészetek egyik válfaját sem azonosítani teoretikus (esetleg nyelvfilozófiai) irányzatokkal, helyénvalónak érezzük a kritikus megjelölést. Nem egyszerüen a nyelv megújításáról vagy továbbfejlesztéséről van szó, hanem az önállóan és egymástól elkülönülten létező mindennapi és költői nyelvnek egy mozdulattal történő átfogásáról és felülbírálásáról. A hagyományos magyar líraértékelés, belülről nézve, a költők nyelvteremtő tevékenységét tekintette elsődleges értéknek, megfeledkezve arról, hogy a költők nyelvteremtése tulajdonképpen stilisztikai fogások újraalkalmazását jelenti csupán, $\mathrm{s}$ a nyelv ornamentális lehetőségeinek bővítése, illetve túlfeszítése, amellett, hogy a költészeten kívüli nyelvet teljesen figyelmen kívül hagyja, általában csak a költői nyelvhasználatnak már érintett illusztratív (variációkra, mellérendelésekre építő) alkalmazását segíti elö. A nyelvkritikusi attitüd, tudomásul véve és állandóan tudatosítva a költészetnek fogalmából következő nyelvbe ágyazottságát, a kifejezés lehetőségeit és korlátait vizsgálja, s a költői beszédformákat mint sajátosan 'jelentéses' egységnek lehetőségeit kutatja. Ebben a kísérletező kutatásban a nyelvi jelentés és a nyelvi kifejezésforma azonosnak tételeződik, s ez az azonosság mint tény, mint tényként felfogott kommunikációs jelenség szegül szembe a hagyományos költészetmodellnek - teóriáján belül - versen túl tételezett eszmefelfogásával." MARGÓCSY István: Jegyzetek a hetvenes évek lírájáról. = Mozgó Világ, 1980/6., 111.

${ }^{288}$ Fehérlófia. $38-39$. 
hierarchiákat megszüntetve. Az alulpoetizáltság, deretorizáltság, a mindennapiság egyszerüsége (bár ez is a poétika eredménye) Kemenes szövegét a hetvenes évek meghatározó poétikájához, a konkrét költészethez közelíti. Ebben a költészetben a szó kap kiemelt szerepet, a szintaktikai rendszerek széttördelése, mely az összefüggések megakadályozását eredményezi. A szó eloldása a szintaktikai rendszertől a tipográfia segítségével is történik. Az íráskép jelentéses szerepűvé válik, az üres helyek szintúgy. „A konkrét költészet úgy 'bontja', 'rombolja' a nyelv grammatikai-szintaktikai szabályait, hogy azokat különböző, új, lehetséges rendek szerint építi fel, 'kiteríti' a nyelvet az olvasó elött, aki így megtapasztalja 'a nyelv határaiban a világ határait' (Helmut Heissenbüttel), és a nyelv felszíni struktúrái alá is 'beférkőzik'. A konkrét vers nyelve nem 'jelentő' nyelv, a müalkotás mindig maga hozza létre azt a generatív szabályt, amiből 'saját' nyelve létrejön." 289 A fenti beidézett szövegrészben ez a „generatív szabály” a felsorolás. A központozás hiányában az olvasónak fokozottabban kell figyelnie a szintaktikai egységek határaira. Az „új költészet formája eszközétől függ - a szótól - mint céltól. (...) A szó kiterjedés. Az - akkor is, ha mondják, akkor is ha írják. Sem jó, sem rossz, sem igaz, sem hamis. Hangokból áll, betükből, melyek közül mindegyik egyéni és markáns kifejezőerővel bír. (...) Más szavakkal való kapcsolatában viszont meg akarjuk tartani a saját egyéniségét, ezért konstelláció formájában rendeljük hozzá más szavakhoz."290 - írja Gomringer. Számos példát hozhatnánk Kemenes szövegéből, amelyben a szó és betüinek kombinatorikája történik, és ahol a szóhatárok is feloldódnak, az egymással kapcsolatba állított szavak sajátos játékteret, konstellációt hozva létre ezáltal.

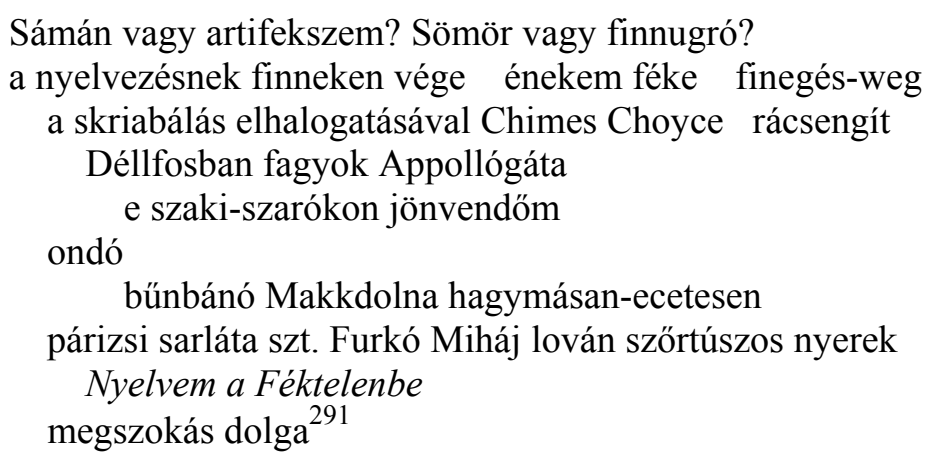

Ebben a szövegrészletben a tipográfia kiemelt szerepe is láthatóvá válik, hiszen azzal, hogy képileg látványos, elkülönített helyet és teret kap az „ondó”, ezzel a szövegrész nemiséggel kapcsolatos elemeit teszi hangsúlyossá. A konkrét költészetben „valamit a hagyományos értelmével ellentétben használnak, anélkül, hogy teljesen eloldanák attól”. ${ }^{292}$ Csak úgy lehetséges az el- és feloldása a szavaknak, ha megőrződik az emlékezetük, egyfajta megszüntetve-megőrző létmód ez a poétikai eljárás is. A fenti példában a kiejtés szerinti nyelvre van rájátszva, ezáltal a nyelvek sokféleségét ezen a szinten is hangsúlyozza, a beszélt és írott nyelv különbségét problematizálja.

Hasonló intenzitással van jelen a szövegben a mese müfaja mellett az önéletírás is. Már így, ha csak egymás mellett említjük a két müfajt, rögtön látszik, hogy radikális változásokat idézhet elö egy klasszikusan értett önéletírás mellett a mese megjelenése. Legfontosabb kritériumát kérdőjelezi meg, a valószínűségét, hitelességét. Az újabb önéletrajz-értés pontosan

${ }^{289}$ KULCSÁR-SZABÓ Zoltán: Oravecz Imre. Kalligram Könyvkiadó, Pozsony, 1996. 29.

${ }^{290}$ Eugen GOMRINGER: A verstöl a konstellációig. Egy új költészet célja és formája. = Magyar Mühely, 1998. tél/1999. tavasz, 108-109. szám, 45, 46.

${ }^{291}$ Fehérlófia. 35.

${ }^{292}$ Helmut HEISSENBÜTTEL: Konkrét költészet. = Magyar Mühely, 1998. tél/1999. tavasz, 108-109. szám, 42. 
ezt a referencialitást bizonytalanítja el. Kemenes szövegében ezen architextus mise en abymejaként is értelmezhető Fehérlófia 5: P. Arthur önéletírása (Töredék), „amelyben a szerző kéri a nyájas olvasó türelmét és elnézését, azután pedig ismerteti születése körülményeit, azazhogy hol, mikor, hogyan és miért jött erre a világra", és ebben a fejezetben szintén egy csodagyerek (hét foggal született, ami a táltos voltra utal) születésének a története van elmesélve. A második fejezet kivonatával fejeződik be, azaz töredékessége jut érvényre. Ez a tükörszerkezetet képviselő fejezet már önmagában a fragmentaritást tükrözi, az önéletírás nagy elbeszélésének lehetetlenségét, csupán egy fejezet mesélhetö el, és az is hosszas - az Olvasóhoz intézett - reflexióval. A Fehérlófia egészében meghatározó az önéletrajziság, adott esetben a referencialitás ('56 és az emigráció központi motívuma a szövegnek), de ugyanakkor a szerteágazó szövegtípusok, diskurzus elemek hatására csupán töredékesen érvényesülhet. Az eposz müfaji jegyei szintén kontúrszerüen vannak jelen. A szöveg a „bébi Babits"-hoz intézett invokációval kezdődik. Az, hogy a segítő múzsa itt egy költő, ugyancsak önreflexívvé teszi a szöveget. És azt mondhatjuk, a seregszemle, az enumeráció itt a világirodalom és a magyar irodalom szerzőinek a felvonultatása, szövegeiknek (meg)idézése. Az eposzi hős mindamellett, hogy (forradalmi) hős, időnként gumiszívvel és az agyat helyettesítő kvarcmotorral rendelkező báb. ${ }^{293}$ Ugyanígy a tragikus hőstípus is obszcén elemekkel társul. Azt mondhatjuk, hogy a Fehérlófia úgy ötvözi a különböző müfajokat, hogy megtartja bizonyos sajátosságaikat, de egyiket sem teszi fölérendelt pozícióba. Az eddigi műfajmeghatározás-kísérletek is ezt mutatják, bármilyen kompromisszumos, újonnan létrehozott összekapcsoló müfajmegjelölés elégtelennek bizonyul, mivel csupán a szöveg bizonyos aspektusait képes jelölni. ${ }^{294}$ Ezért javasolom a müfajok esetében is a kollázsszerüség kiemelését, mert ahogyan az idézetek, szövegtípusok egymás mellé kerülnek szinkronszerüen, ugyanúgy történik a müfajokkal is, hiszen nem elvonatkoztatva léteznek mint kristálytiszta formák, hanem új megfogalmazásokban realizálódnak. A Fehérlófia poétikai eljárásainak legfontosabb meghatározói a kollázs, a montázs és a palimpszesztus. Ez utóbbi a Fehérlófia második könyve XX. fejezetében konkrétan is megjelenik (Első felvágás, második felvágás stb.), ugyanakkor metaforikusan kifejezi azt, hogy az éppen olvasott szöveg mögött újabb szövegrétegekre bukkanhatunk, de amely rétegek egymás viszonylatában válnak értelmezhetővé.

A töredékesség és egészelvűség kettősége azért is lehet szinkronszerüen együttes meghatározója ennek a könyvnek, mert egyszerre alkalmazza a próza, a líra és dráma münemek sajátosságát. Így olyan sajátos konstellációt teremtve, amelyet széttartó volta miatt nehezen lehetne kimerítően elemezni. Ez a fajta szövegszerveződés a rizóma (DeleuzeGuattari) müködéséhez közelít. „A rizóma nem kezdődik és nem végződik, mindig középen van, a dolgok között, köztes lény, intermezzó."295 Müfajok, műnemek kollázsa révén ugyanakkor a müfajokról való tudásunk is az átértelmezés dinamizmusába kerül, hiszen ahogyan a regény kapcsán Bahtyin már elemezte - az ilyen egymásra hatásokban a múfaj mint elvont kategória állandósultságából fog kimozdulni, azaz „megújulni”. Bahtyin azt írja,

\footnotetext{
${ }^{293}$ Vö. „Ránk adják a fekete posztóöltönyt/ Lábunkra húzzák a spanyol lakkcsizmát/ Orcánkat kirúzsozzák ujjainkat összekulcsolják/ Plasztikgombócot nyomnak a szánkba/ A meghasadt szív helyére új gumipumpát tesznek/ A lottyadt agy helyére kis kvarcmotort szerelnek/ Üveggyapot tüdőcskét raknak a mellkasra"

${ }^{294}$ Pomogáts Béla kísérletei például a „lírai eposz” és a „önéletrajzi költemény”. Vö. A montreáli végvárban. Kemenes Géfin László verseiröl. In: Változatok az avantgárdra. Budapest, 2000. 303307.

${ }^{295}$ Gilles DELEUZE-Félix GUATTARI: Rizóma. http://www.c3.hu/ exsymposion/HTML/fu/deleuze/ foszoveg.htm 14.
} 
hogy a regény megjelenésével megfertőződnek a más müfajok, és másképpen kezdenek hangzani a hatására. Ezekben a közöttiségekben látom a neoavantgárd-poétika legföbb sajátosságát. Ezt a közöttiséget úgy definiálhatnánk, hogy a különbözőségek nem csupán egymás mellé felsorakoztatnak, hanem az egymásra hatásuk lesz lényeges. Ez több szinten is megfigyelhető: szövegközöttiség, nyelvek közöttisége, műnemek, müfajok kollázsa, rizomatikus „,narratíva”.

Ahhoz, hogy hatékony legyen az általam terminus (technikus)ként használt közöttiség kategória, úgy gondolom, hogy értelmező kontextusba kell „,beszőni”. Ebbéli törekvésemben nagyon jó viszonyt kínál Renate Lachmann által értelmezett „másodlagos szinkretizmus” fogalma, amelyet orosz példákon dolgoz ki. Lachmann megkülönböztet archaikus szinkretizmust, ahol a kommunikáció polifunkcionális (zene, tánc, költészet egyidejü jelenléte) és másodlagos szinkretizmust, amely a „tiszta stílus” eszményéből következő stílushierarchia és ezt létrehozó restriktív szabályok ellenében, ellenreakcióként jött létre. Magukat a stílusformákat, az egyes stílusokat az emlékezet hordozóinak tekinti, így „az intertextuális szövegben a szinkretizmus a heterogén stílusok és a bennük felhalmozott szemantikai és kulturális tapasztalatok szinkronizálását, kontaminálását szolgálja". ${ }^{296}$ Kettős kódolás jön létre, ugyanis az idegen stíluselem egyrészt beépül a megidéző szövegbe, ugyanakkor megőrzi idegenségét is. Amíg a „tiszta stílus” bűvkörében gondolkodunk, addig a stíluskeverés (szmes - Majakovszkij), a határátlépés szabálysértésnek minősül. Azonban a szinkretizmusban pontosan ez a keveredés, kreolizáció (Lotmann), hibridizálás (Bahtyin) válik stílussá, azaz a szinkretikus stílus nem csupán ellen- és eltérö stílus, hanem metastílus egyben, ugyanis reflektáltat magára a stílusra mint olyanra. Bahtyinhoz képest Lachmann a stílusok egymásra hatásában a szemantikai differencia disszharmonikus, monstruóz, súrlódó aspektusát is hangsúlyozza. Bahtyin a dialogikus kategóriájában a „,(ki)békítő” vonást erősíti fel a nyelvi interferenciában. ${ }^{297}$ Bettine Menke szavaival így foglalhatjuk össze a másodlagos szinkretizmus jelenségét, hogy ,,az összegyüjtött elemeket megtartja saját idegenségükben a bevezetett idegen elem heterogenitásának elpalástolása nélküli szintézisként"298, vagyis egyszerre összegző és szétbontó, nem hozzáadó, hanem bennefoglaló a szinkretizmus. Benne az időbeliség térbeliesül, a kulturális emlékezet diakronikus felduzzadása ( $\mathrm{pl}$. a palimszesztben), egymásba íródása történik a szöveg színterén (mise-en-scene). Találó allegorézisre ad alkalmat a Fehérlófia nyolcasa. Hardcore. Szerelem. Cirkusz (1995) címü könyvben a ,szövegbicikli, amelynek kereke nyolcast kapott” kép, amely a könyv más pontjain is visszatér. ${ }^{299}$ Ugyanis a kerék mint zárt mezöny, rács, de amelynek belsejében

${ }^{296}$ Renate LACHMANN: A szinkretizmus mint a stílus provokációja. = Helikon 1995/3., 267.

${ }^{297}$ A szó esztétikájában kijelenti, hogy semleges megnyilatkozás nem létezik, ,az egyedi, konkrét megnyilatkozás mindig valamely értékelő és értelmező kulturális kontextusban, személyes életszférában hangzik el”. Továbbá: „Azokat a megnyilatkozásokat nevezzük hibrid konstrukcióknak, amelyek grammatikai (szintaktikai) kompozíciós jellemzőjük szerint egyetlen egy beszélőhöz tartoznak ugyan, de amelyben két megnyilatkozás, két beszédmód, két nyelv, jelentés és értékelés két horizontja keveredik." (Mihail BAHTYIN: A szó esztétikája. Gondolat, Budapest, 1976.) Dosztojevszkij elemzései során a megnyilatkozások szintjéről e keveredés a szó szintjére is átkerül, a kétszólamú szó kategóriájával a szó dialogikusságát hangsúlyozza.

${ }^{298}$ Idézi Renate LACHMANN: i. m. 277.

${ }^{299}$ Vö. „hát így megy ez a szövegbicikli amelynek kereke nyolcast kapott döcögve megy csak...” (6. oldal), ,az írás turbulencia, túldeterminált jelentésesség amit a Főnök (író úr) nem tud kontrollálni kicsúszik a szándék mint a betűk az írásból csilingelve le a járdaszélre” (24. oldal), „MERT MAGÁNBESZÉD LETT a sorsírásból, belső dialógus, nem világos ki kihez szól kire hallgatde azért föl a rozoga bringára, elférünk minden, ki a vázon ki a csomagtartón ki csak integet” (72. oldal) 
kombinációk jöhetnek létre, úgy módosul a nyolcas révén, hogy maga a rendszer (illúziója) megmarad, de a maga sérültségére irányítja a figyelmet. Ismét a rizomatikus szerkezethez kapcsolódhatunk vissza, annak Eco által adott értelmezéséhez: „A rhizóma-labirintus olyan sokdimenziósan van megszőve, hogy minden járata összeköthető az összes többivel. Nincs sem középpontja, sem perifériája, még kijárata sincs, hisz potenciálisan végtelen." (A lefektetett nyolcas szintén a végtelen kifejeződése.) Kemenes meta-metaforájába e kontextus hatására láthatóvá válik ismételten a közöttiség létmódja, hiszen a biciklikerék szerkezetében elvileg a középpont elképzelhető, illetve az arra való irányultság, de nem érnek mégsem össze a különböző irányból jövő szárak, szálak, hiszen ha összeérnének, müködésképtelenné válna a rendszer. Ez egy olyan „középpont” tehát, ahol különböző szálak forognak egy időben. Azon kettősség, közöttiség (és nem átmenetiség) kifejeződése lehet a fenti kép, ahol egyszerre van jelen a sokdimenziós megszőttség (három teljesen különböző történet szövődik), ugyanakkor a középpont emlékezete is felsejlik (ez főként az egyes történetekben az elbeszélök önmegértési mint teleologikus folyamatában, a személyi integritás vágyában érzékelhető), de amely pontosan a sokdimenziós megszőttség hatására sohasem realizálódhat (egyetlenként). A szöveg további olvasás alakzatokat kínál:

mégha eme aktusunk által létezővé is varázsoljuk azt a másikat az amőbát mert mi van más mint uralkodás és megalázkodás

homeosztázisz amőbaság a teljes osztódás felszívódás állapotában

$\mathrm{s}$ ami addig amőba volt most íme nő lett annak a tudatnak a rabja hogy ő most van valamiért

j'attendrai hol júliára talála she walks in beauty minden félrecsúszott nyakkendőmben élsz

da unzer zweier bette was

és uralkodol

(33. oldal)

A történet deformálja az életet, hogy formát kölcsönözzön a máskülönben szétmálló amőba-anyagnak."

(34. oldal)

Az idézetek amellett, hogy a fent már tárgyalt nyelvhasználatok egymásra hatását is példázzák, az amőbaság jelenségét kínálják értelmezésre. Benne azon képlékenység, változékonyság (a környezetéhez, a táplálékhoz formálódik, állábakat bocsát ki, és folyton átalakul a teste), decentralizálódó aktus (osztódással szaporodik) fejeződik ki, amely hatékony olvasásalakzatként szolgál. Az amőba mozgása hasonlóvá válik a Deleuze-Guattari-féle rizóma müködéséhez: „A nem-jelentő szakadás elve: a túlságosan jelentő törések ellen, melyek struktúrákat választanak el, vagy áthaladnak bizonyos struktúrán. A rizóma bárhol megszakítható, bárhol megtörhető, hiszen vonalai mentén újból lesz.” „,...a rizóma, térkép és nem másolat. Térképrajzolás és nem másolatkészítés. (...) A térkép maga is része a rizómának. Nyitott, minden irányban kapcsolható, szétszedhető, megfordítható, kész minden pillanatban változni." ${ }^{300} \mathrm{Az}$ amöbaság mint de-formáló szövegszerveződési módozat esetében külön hangsúlyossá válik a tipográfiai elrendezés, amely lehetővé teszi például a fenti szövegrészletben a „valamiért élsz és uralkodol” szavak összeolvasását, ily módon egy másik szálat, kapcsolódást alkotva.

Történeti következtetés is levonható: a posztmodern teljes feloldódáshoz, eloldódáshoz képest itt inkább az irregulatív szabályozott rendszerének közöttiségével van dolgunk.

${ }^{300}$ Gilles DELEUZE-Félix GUATTARI: i. m. 4. 6. 
Ugyanakkor a közöttiség az elbeszélöi nemek szintjén is létrejön, az egyik történet egy amerikai lány önmegértési kísérletének a folyamata. A Fehérlófia nyolcasában a Nöi Alany (szövegbéli meghatározás) mássága kulturális, nyelvi idegenséggel is társul. Itt most csak egyetlen példát emelnék ki annak bemutatására, ahogyan a szöveg köz-helyessé teszi a nőférfi klasszikus oppozíciót. „(...) a végén megkérdeztem tőle miért gyülölsz annyira minket igen minket nöket miért van benned az a szinte hihetetlen harag bosszúvágy a szándék hogy amikor csak lehet megszégyeníts bennünket megalázz letörj összezúzz mint valami kártékony rovart. D. megállt az ajtónál nem nyitotta ki de nem is fordult vissza felém. Mert nem hagytok bennünket békén mondta alig hallhatóan, nélkülünk semmik se lennétek olyanok vagytok mint az amöba azért kellünk nektek máskülönben szétfolynátok, de hát ez is közhely mint mi magunk is az vagyunk." (84. Kiemelés: D. M.) A látszólagos férfi instancia, viszonyítási pont úgy válik köz(tes) hellyé az amőba-nő viszonylatában, hogy reflektál saját köz(-)helyes önmeghatározására, ezzel a beszédmóddal mintegy viszonylagosítva a szétfolyás-határt jelölő oppozíció alapját képező férfi auktoritást. ${ }^{301}$

További vizsgálódás alapját képezheti az írás és hang eltérő medialitásának erőteljes problematizálódása a szövegben, egy másik szinten pedig a szinkretizmus multimediális aspektusa, a színpadra vitel, ugyanis a keret (kerék) a szövegben egy film rendezése.

\section{Intertextualitás: létmód vagy bazári jelleg? Vitéz György $A$ fényképésznél címü szövegének olvasatai}

Itt következő elemzésemben az idézésmód milyenségére figyelve szintén a neoavantgárd poétika sajátosságait szeretném árnyalni és a neoavantgárd-posztmodern korszakolás tekintetében is következtetéseket levonni.

Az alcímben megjelölt szövegben az álom mint történés lehetőséget teremt az állandó mozgásban, intertextuális kapcsolódásokban létező szövegvilág müködésének a tematikus megfogalmazására. A szöveg szerveződésének az álomszerü történés válik a meghatározójává, „csak az álom teheti meg ezt, csak”. Ezt a kijelentést reflexív, metatextuális elemként olvashatjuk, hiszen a szöveg történésének a metaforája. Az álomban idő- (például a „vásári fényképész" és a videó egyidejü jelenléte) és térviszonyok elmosódnak, és előtérbe egyfajta labirintus jelleg kerül. Ebből a szempontból az „Ariadné fonala” a labirintusra és Thészeuszra utaló mitológiai allúzió szintén a szöveg szerveződésének hogyanjára reflektáló metatextuális elemként lesz olvasható, hasonlóan továbbá a „logocentrifuga”, „bazári jelleg”, „minden csak töredék foszlányok" kijelentések is. Az álom mint a szövegszerveződés azért is kiemelten hangsúlyos, mert az álomban az álmodó szubjektum nem irányíthatja a folyamatot, nem ura a történésnek, hanem vele történik. Ebből a szempontból az elbeszélö összetartó, centralizáló képességéről nem beszélhetünk, hogy tehát ő válogatná ki és vágná össze a különböző szövegeket. Az álomszerü történés a beszélö szövegválogató, irányító funkcióját eliminálja, annyiban létezik csupán, mint beszélő, amennyiben ezen a történésen belül jön létre. Ebből következően a decentráltság válik a szöveg jellemzőjévé. A létrejövő müalkotás nem uralkodik a hagyományon, nem illusztrációként, indoklásként emelődnek be idézetek egy úgynevezett főszövegbe, hanem a létrejövő szöveget magát a különböző idézetek, különböző nyelvi regiszterek, extratextuális elemek határozzák meg, illetve e szövedékben, e különbözö regiszterek egymásra hatásának eredményeképpen keletkezik. A „logocentrifuga” beszédmód annak kifejeződése lehet, hogy hogyan ölt „bazári jelleget” e különböző hagyományok, regiszterek egymásra hatása. Viszonylagosítódik az irodalmi és nem irodalmi elkülönítés. E

${ }^{301}$ Az amőba önkényes értelmezését is leleplezve, hiszen az nem szétfolyik, hanem alakját változtatva mozog. 
kettő közötti oppozíció felszámolódik, e szöveg nyelve már nem úgy hozza létre az irodalmi, esztétikai nyelvet, hogy annak megkülönböztető sajátossága lenne a hermetikus elkülönülés más nyelvi regiszterektől. A nyelvi kódváltások dezautomatizálják a befogadási folyamatot, az intertextusok, az extratextuális elemek folyton alakítják az elváráshorizontunkat, ugyanakkor a különböző diskurzustípusok relativizálják is egymást, ennek megfelelően a szöveg müfajisága is meghatározhatatlanná válik, illetve egy olyan müfajhoz áll a legközelebb, amely maga összekapcsoló, kettős műfaj. A prózavers vagy verses próza egyszerre juttatja érvényre a két münem sajátosságait. Schein Gábor szerint „a próza és a vers közötti különbség végső soron nem más, mint szemantikai tagoltsággal interferáló ritmikai szegmentáltság, ami meghatározza a verssorok szerkezetét és egymásutánját, ugyanakkor nem jellemző a prózára...”302 Ahol a szegmentáltság nem esik egybe a mondat szintaktikai tagoltságával, tehát a szegmentumként értett verssor olyan ritmikai egység, amely eltér a mondat egységétől. „A verssorok létmódját tehát, minden esetben ritmikailag motivált szünetek határozzák meg." ${ }^{303}$ A szegmentáltság szemantikailag is megváltoztatja a beszéd jellegét, mivel a tagolás révén poétikai viszony jön létre különböző nyelvi jelek között, amelyek sem grammatikailag, sem szintaktikailag nincsenek összetüzve. Ily módon Vitéz szövege olvasható epikumként, ekkor a linearitás, a folyékony, mondathatártól mondathatárig tartó beszéd lesz a meghatározó, melyet azonban a reflexiók helyenként megszakítanak; vagy értelmezhető versként is, és ilyenkor a verssorokat szegmentumokként olvassuk függetlenül a szintaktikai egységtől. Szembetünővé válnak az enjambement szerepe, amely ,az elhalasztódó különbséget teszi hatékonyabbá". ${ }^{304}$

vőlegény. Sarkonfordulok. kettős anakr(e)onizmus: meglepetés e

költemény - csak az álom teheti meg ezt, csak. Gavrilo princípiuma:

Az írásban elhalasztódó „költemény” kiemelt funkciót kap, beszédbeli és írásbeli különbsége hangsúlyozódik. Ugyanakkor a szegmentáltság szerint viszony teremtődik a „költemény” és „álom” között. Itt maga a szöveg így müködő retorikája teremti meg az összekapcsolás lehetőségét. A tagadószóval végződő sorok teszik a legnyilvánvalóbbá a kétféle olvasás lehetőségét, hiszen teljesen ellentétes jelentés jön létre ha beszédszerüen és ha írásképszerüen olvassuk. A fenti sajátosságok révén (álom mint „szervezőelv”, decentralizáltság, müfaji határvonalak fellazítása) a szöveget a posztmodern esztétika kontextusába tartozónak láttatja. Azonban a szöveg nem az álomleírással kezdődik, hanem a „Hölgyeim és uraim, nagyérdemü közönség!" megszólítással, amely egy külső keretet képez az álomban történő jelölők játékának, ily módon azt mondhatjuk, hogy azt a dezorganikusságot, decentralizáltságot, amelyet az álomrész hoz létre egy centralizáló beszélő fogja össze végső soron egy keretbe. És eléggé hangsúlyos pozíciójú beszélő, de aki mint előadó, színész lesz meghatározható, tehát egyfajta szerep identitásnak a kifejezője. Azonban ez nem tudja megváltoztatni e kezdő mondat centralizáló jellegzetességét. Ez a szövegkezdő aposztrophé azzal együtt, hogy létrehozza hallgatóit, egy olyan beszélőt is tételez, aki mindezt végrehajtja. Tehát az álom létéből következően beszélhetünk álmodó és álmodott szubjektumról és egy olyan beszélőről, aki mindezeket elmeséli, aki a megszólítást a hallgatósághoz intézi. Jonathan Culler szerint

\footnotetext{
${ }^{302}$ SCHEIN Gábor: A ritmikai szegmentáltság mint a vers kompozícios elve. = Alföld, 1994/12., 42.

${ }^{303}$ SCHEIN Gábor: $i . m ., i . h$.

${ }^{304}$ Uo. 41.
} 
„az aposztrophé (...) elfordulása az olvasótól a lírai én mint beszélő létét alapozza meg”. 305 Tehát mivel az aposztrophé látszólagos (vö. frázis jellege ennek a megszólításnak) kapcsolatteremtés a megszólítottakkal, pusztán a beszélőre vonatkoztatódik vissza, őt létesíti, a megszólítottakat hallgatókként szituálja, így meghatározóvá a monologikus beszédmód válik. Az intertextualitás széttartó jellegét ezen elbeszélő történetszerü monológja ellensúlyozza. A történetszerüség, mely linearitást implikál a szöveg összekötő elemeiből is következik („közben”, „azután”). Ugyanakkor a metatextuális utalások gyakori jelenléte, szintén az önmagára utalással a szabad és szertelen áradás megfékezését eredményezi. Az intertextualitás delinearizált időbelisége mellett a történetszerü elbeszélés lineáris időkezelést érvényesít. A múlt idejü állítmányokat figyelve úgy tünik, hogy a narráció irányítójává az emlékezés tevékenysége válna, ugyanakkor az intertextualitásból adódó töredékesség, „bazári jelleg" a bármilyen reprodukció lehetetlenégét képezi le, ily módon megkérdőjelezve azt a rekonstruktív elbeszélői pozíciót, amely az álom felidézésére tesz kísérletet. E felidézés csak foszlányok bazári jellege lehet, „nyomok középpontnélkülisége” (Derrida). Ugyanakkor a megszólításból kiindulva az álomelmesélés kísérlete úgy is értelmezhető, mint egy szórakoztató történet kitalálása. Ekkor a töredékesség nem az emlékezésből adódik, hanem a képzelet teljesítménye. Ebből a szempontból a szöveg saját létrejövését írja le.

Az mondható tehát, hogy egy olyan kettőség jegyében válik értelmezhetővé a szöveg, mely szerint az intertextualitásban létrejövő decentralizáltság végső soron csak egyik sajátossága a szövegnek, belső eleme egy beszélő pozíciót létrehozó keretnek. Bár látjuk, hogy ez a keret önmagában is kettőség kifejezője (vö. szerep, színész, klisé). Mindezek hatására már nem olyan egyértelmü, hogy a szöveg - a jelölők játékában a beszélői identitást feloldó posztmodern alkotások közé sorolható. Annál is inkább, hogy az intertextualitásban sajátos módon érvényesül a referencialitás, amelyet viszont a posztmodern nem ismer el. Gyakran nem szövegek kölcsönhatásáról van szó, hanem a politikai, történelmi utalások esetében a pretextust egy referencia képezi. Irodalmi utalások esetében is, például Babits és Kafka esetében is ezt észlelhetjük. A megidézett cím, szerző, szereplő mint referenciák szerepelnek. Ezekben az esetekben tematikus intertextualitásról van szó. Összetettebb a Szabó Lőrincre való utalás (,Azt álmodtam”), ez hipertextuális elemként értelmezhető ${ }^{306}$, ugyanakkor szerkezeti intertextualitás is, az álom az álomban szerkezet átvétele. Tükörszerkezetre még egy példa található a szövegben: a kezdőformula az előadás szituációját teremti meg (az olvasó mint hallgató van szituálva), ugyanakkor Timár Virgil a szövegben ,int valami láthatatlan hallgatóságot", vagyis az előadás az előadásban-szerkezet jön létre. A József Attila intertextusok közül egyet emelnék ki, amely a mondat szerkezetével és ritmikusságával utal a „Visz a vonat megyek utánad/ talán ma még meg is talállak” sorokra. Úgy gondolom, hogy a „Visz a lábam mintha robot lennék” pontosan annak a mechanikusságnak a megfogalmazása, amelyet a Mellékdalban lévő mondatszerkezetek (sorrend) kiváltanak. Ez az álom jellegére is utaló mondat, átírhatja a Mellékdal értelmezését is: „Visz a vonat” így, ezért „,megyek utánad”

305 Idézi KULCSÁR-SZABÓ Zoltán: A „te” lírai alakzatának kérdéséhez. = Uö.: Az olvasás lehetőségei. JAK füzetek, Kijárat Kiadó, 1997. 47. Vö. továbbá: „Az aposztrophé látszólag az én és mások között létesít kapcsolatokat, valójában azonban az interiorizáció és a szolipszizmus aktusaként olvasandó. Egyfelől ugyanis - szinekdochékkal élve - mintegy szétszórja az ént a világban, másfelől pedig interiorizálja a megszólítottakat (amennyiben olyan dolgokhoz fordul, amelyeket nem lehet 'te'-nek szólítani, csak akkor, ha az 'én' részeiként - például tudatában jelennek meg). Tehát az aposztrophé tárgya csak abból a szempontból érdekes, hogy milyen hatással van arra, aki beszél, nem dolgokra utal, hanem a beszélöre vonatkozik."

${ }^{306}$ Ugyancsak hipertextualitásként értelmezhető a KARINTHY Frigyes Cirkuszára való utalás, mivel tematikusan a pretextus egészét érinti, ugyanakkor továbbírva ezt a textust. 
és az okozati sorrend nem fordított tehát. Ez a szövegrész példa lehet arra, hogy az intertextuális viszonyrendszerben a szövegek kölcsönösen átírhatják egymást.

A prózavers müfaja az eposzi hagyománnyal is viszonyba lép. Ha nem ismernénk fel a „Régi dicsőségünk”, „hősvértől pirosult”, „századok ültenek el”, „sóhajtva köszöntlek” „,arma virumque" konkrét szöveghelyét, akkor is az eposzi hagyományhoz való kapcsolódásukat érzékelnénk. Az idézetek a pátoszt, a Zalán futásának és a Aenaisnak egyik lehetséges esztétikai tapasztalatát hívja elő az értelmezőben. ${ }^{307}$ Az eposzi hagyomány, „váteszi arc”, mint lehetséges identifikáció értelmezhető.

Érdemes még kiemelni a cím szerepét a szöveg interpretációjában. A címadás mint szignifikációs aktus egyféleképpen egységgé szervezi a szöveget, paratextuális viszony jön létre cím és szöveg között. Egy referencializáló olvasatban e mü (a címböl kiindulva) a portrélét, a másolatokban való létezés tematikus megfogalmazása lehet. (Ehhez kapcsolódhat a Kafkára utaló szövegrész.) Szó szerint olvasva a címet olyan helynek feleltethetjük meg, ahol másolatok keletkeznek, metaforikusan pedig a szöveg létrejövésének módjaként: a nem autentikus szövegre, nyelv/hagyomány általi megelözöttségre, feltételezettségre, kulturális tudatra utaló reflexív szövegelemként. Ugyanakkor az is hangsúlyos, hogy egy másik, a kép médiuma vonódik be a fénykép („,Daguerrotipia”) által. A másolat-lét, a megkettőződés valamilyen szinten mindig a kép médiumához is kapcsolódik.

Vitéz verse esetében is, hasonlóan Kemenes müveihez, azon kettősséget kell kiemelni, melyet most már a neoavantgárd jellegzetességének tartok, hogy egyrészt tovább visz avantgárd poétikai elemeket (a prózavers mint müfaj, idegen nyelvi elemek jelenléte), ezekhez viszont olyan idézésmód kapcsolódik, mely a posztmodern megkülönböztető jegye. Azonban, mint ahogyan fent értelmeztem, ez a fajta intertextuális áramlás, nem az egész szöveg meghatározója, hanem keretbe van foglalva, és a kezdősorban ugyanakkor hangsúlyos beszélői pozíció jön létre. Bár a végén nem tér vissza a kezdéshez hasonló formula, így igazából nem is keretről kellene beszélnünk, hanem alaphelyzetről, mely ugyanakkor összefogja a szöveg széttartó intertextualitását. „Az álomnak egyelöre nincs vége...” befejezés, a három ponttal a végén tematikusan a befejezhetetlenséget mondja, de ezzel a reflexív jellegével mégis lezárja a jelölők szabad játékát. Látható, hogy nagyon könnyen besorolható lenne ez a szöveg a posztmodern irodalom címszó alá, azonban azok az árnyalatok, melyeket felvillantottam, szükségessé teszik egy olyan irányzat, korszak elkülönítését, amely nagyon sokban megegyezik a posztmodern irodalom sajátosságaival, de lényegi pontokon eltér tőle. Ez a korszakküszöb, közöttiség, amelyben az említett kettőségek egyidejüleg vannak jelen, lehetne a neoavantgárd.

\section{Kísérlet történeti következtetésekre}

Kiindulópontként álljon itt Szabolcsi Miklós neoavantgárd értelmezése: „A neoavantgarde időben és tartalomban körülhatárolható jelenségcsoport, áramlatköteg. Nem azonos a 'klasszikus avantgarde' feltámasztásával, nem azonos a kétségbeesés irodalmával sem, hanem általában (de nem mindig) mozgalomszerủen, szervezett módon megnyilvánuló, csoportok által hordozott irodalom, amely - s ezért avantgarde - ugyancsak a müvészet és társadalom radikális megújítására tör, de $-\mathrm{s}$ ezért neo - lényegesen új társadalmi, technikai, történelmi

307 Vö. „Azzal, hogy egy szöveg valamilyen úton egy másik szöveget jelöl, illetve arra utal, a befogadás során nem azt a szöveget hívja elő a maga grammatikai megvalósulásában, hanem a befogadói horizontot strukturálja át azáltal, hogy előhívja az utalt szöveg esztétikai tapasztalatát." KULCSÁR-SZABÓ Zoltán: Intertextualitás: létmód és/vagy funkció? = Irodalomtörténet, 1995/4., $518-519$. 
körülmények között. Azt is meg kell jegyeznünk, hogy ha lehet, még közvetlenebbül kapcsolódik a politikai mozgalmak különféle fajtáihoz, mint a klasszikus avantgarde. Ugyancsak erősebb a kapcsolata a filozófiai alapokkal is, olykor szinte pusztán az elméletben jelentkezik." 308 Látható, hogy az avantgárdhoz való erős kapcsolódás hangsúlyozódik ebben a definícióban, ezért is kaphatta a neo elötagot. (Azonban azt is észre kell vennünk, hogy Bürger meghatározásának az ellenkezője volt itt olvasható. Ugyanakkor jól körülhatároltságról is el lehet mondani, hogy pontosan Szabolcsi tanulmányában lesz elkülöníthetetlen a felsorolt sajátosságok mentén a neoavantgarde és a posztmodern.) Mára azonban a hatástörténet bebizonyította, hogy éppen olyan jelentésessé vált a történeti avantgárdtól való eltérés és a posztmodern paradigmához való kapcsolódása. Sokkal szerencsésebb lenne éppen ezért a posztavantgárd elnevezés, mivel ebben nem szünne meg az avantgárdhoz való kapcsolódás kifejeződése, de a poszt révén csak az időbeli utólagosság hangsúlyozódna, értékvonatkozások nélkül, amelyek a neo-ban viszont benne vannak. A jelhasználat szempontjából a neoavantgárd eltérni látszik a történeti avantgárdtól, ugyanis kiemelt szerepet kap a nyelvi, kulturális hagyomány és ez a klasszikus modernhez kapcsolja, ugyanakkor a posztmodern irányába mutat. A kollázstechnika, mely a történeti avantgárd poétikájából eredeztethető, viszont olyan intertextualitással társul, mely révén a hagyomány szerepe ismételten megnő, mert az avantgárddal ellentétben nem tartja legyőzhetőnek vagy megtagadhatónak, és ez ismét a posztmodern felé közelíti. Ugyanakkor a kollázstechnikából következően a fragmentaritás lesz a meghatározó, a „mű már nem egy szerves egészként jön létre, hanem töredékekből montírozott”309, a nagy elbeszélés lehetetlennek bizonyul, „a stílusok és eljárásmódok történeti sorrendje a radikális különbségek egyidejüségébe transzformálódott". ${ }^{310}$ Azonban míg a posztmodern paradigma sajátossága a decentráltság az intertextuális hálózatban, addig a neoavantgárd szövegekben az én-be vetett hit megörződni látszik. Viszont az olyan sajátosságok, mint a magas és tömegkultúra szétválasztásának ellehetetlenítése, vagy a müfogalom feloldása ${ }^{311}$, az „opera aperta” (Umberto Eco) kialakulása, a különböző írásrendszerek, műfajok, münemek keverése, ötvözése, vagy a különböző kultúrák, nyelvek viszonyba állítása, összekapcsolása - mindezek olyan sajátosságok, amelyek a posztmodern paradigmában felerősödve folytatódnak. Továbbá a neoavantgárd a médiumok egymásra hatását is kiemelten hangsúlyozza, új müfajokat, kifejezésformákat teremt ezáltal, a technika eredményeit funkcionálisan beépíti müvészet koncepciójába.

A klasszikus modernség, avantgárd és posztmodern trichotonómia kontextusában érzékelhető, hogy a posztmodern paradigmát megelőlegezi a posztavantgárd (neoavantgarde) paradigma, amely az avantgárd és posztmodern között helyezkedik el, és amely - ma úgy tünik továbbvisz az avantgárd technikákból, de lényegesen el is tér tőle, főként a hagyományhoz való - nem tagadó - viszonyulásában, ugyanakkor előfeltétele is a posztmodern idézésmód, esztétika kialakulásának. Bármennyire is nem szeretném genealogikus konstrukcióban elgondolni a korszakok egymáshoz való viszonyát, most úgy látom, hogy a poszt/neoavantgárd egyfajta elötörténete a posztmodern paradigmának, és azok a sajátosságok, amelyek a

\footnotetext{
${ }^{308}$ SZABOLCSI Miklós: A neoavantgarde. Gondolat, Budapest, 1981. 32.

${ }^{309}$ Peter BÜRGER: i. m. 16.

${ }^{310}$ Uo. 11.

${ }^{311}$ Vö. A ,...neoavantgarde különféle áramlatai a mủvészeti folyamatra, a művészetre, a műalkotásra vonatkozóan is kifejlesztettek különféle elméleteket, illetőleg más körökben kialakult elgondolásokat mintegy a maguk gyakorlatának alátámasztásásra használták fel. A legáltalánosabb válasz a kor kihívására: a müfogalom felodódása, 'Auflösung des Kunstbegriffs'. (...) Nincs tehát egyedi mü, nincs esztétikai szféra sem.” SZABOLCSI Miklós: i. m. 41-42.
} 
neoavantgárdra jellemzőek a posztmodern írásmódban élnek tovább. Mindezekkel együtt önmagában való történeti értéke kell hogy legyen a magyar irodalomtörténetben.

\section{Függelék}

\section{Vitéz György}

\section{A fényképésznél}

Hölgyeim és uraim, nagyérdemü közönség:

Azt álmodtam, hogy azt álmodtam Önök elött állok és egy álmomat mesélem, konferanszié vagyok vagy talponálló komikus (stand up comic), Önök nyugtalanok, figyelmük szerteszét s számosan a kijárat felé tekintgetnek. Félszegen nekikezdek, (K. F. Cirkusza jut eszembe, de a hegedülést már idötlen idők óta nem gyakoroltam s egyensúlyérzékem se a régi). Marad a jólformált süket (és vak) duma, logocentrifuga, a történet piros Ariadné fonala, a nyakatekert (nyaka köré tekert) fonák, akarom mondani fonál, - egyre többen szedelözködnek, köhögés, visszakérik a nyelv alá csúsztatatott obulust, rázzák a szinfalak mögött fejüket fogják verik (a falba)

a rendezö ikrek: Demi John és Urgosz.

Megkapaszkodom a zsinórpadlásról leeresztett szalmaszálba és:

azt álmodtam, vásárban vagyok, régimódi vásárban;

Szarajevo elötti idill, mundérban a férfiak, daliás Radko Mladics vagy Ferenc Ferdinánd; a nök, ersatz Erzsébet királynö, Zsófi a Conti utcai sétahajó, bazári jelleg, -csepürágók, bábosok, bábák, (vö. vasorrú) babák, bakák, (vasárnap várom a bakámat) de nem jön, Carmen imádlak - nem rukkolt be idejében (mint a mondanivaló.) Álmodom, hogy ébren vagyok. Te jó Isten, mibe kerülhetett ez a sok jelmez, a statiszták bére (a félelem bére.)

Kis bódéhoz érek. Érdekes, mintha valami más lett volna itt ezelött. Most vásári fényképész boltja: az ajtó fölött ormótlan cégtábla, Vörösmarty Dauerrotipia. Rá van írva, gót és cirill betükkel, olvasom lelki szemeimmel.

Benyitok az ajtón. Hatalmas müterem, hogy fér be ebbe a vityillóba. Óriási, háromszinü kulisszafüggönnyel nézek szembe. Jókora lyuk a közepében, komótosan elfér benne a kimüvelt emberfö. Piros, fehér/lyuk, zöld. Mögöttem szorgoskodik a fotografussegéd. Rekedtes, elfúló hang a függöny mögül: Attila fiam, profilból videózza az ifjú párt. Ugye tudja, Ond vezér unokája a vőlegény. Sarkonfordulok. Kettös anakr(e)nizmus: meglepetés e költemény - csak az álom teheti meg ezt, csak. Gavrilo princípiuma: oda löj, ahol a kitüntetés fityeg.

Közben kikászálódik a függöny elé Timár Virgil tanár úr. Azt suttogják, kiugrott a rendböl. Botját fölemeli, sigy int valami láthatatlan hallgatóságot: SZÉLRÖL LEGELJETEK, FÁNAK NE MENJETEK, mert ha fának nekimentek, bizonnyal halál fiai lesztek.

Rémülten hallgatom. Hogyan kell szélröl legelni? Mielött visszanyerhettem volna lélekjelenlétemet, kidugja fejét a zöld kendö alól a segéd. Most maga következik, mondotta szárazon, kicsit unottan. Milyen sovány, gondoltam. Talán a vegyszerektöl. Megszólal újra, ezúttal bátoritóbban. Menjen a függöny mögé, 
dugja ki a fejét a körkörös nyiláson és kezdjen hozzá. Mihez,

kérdem tanácstalanul. A skandáláshoz. Ahogy azt a gimnáziumban tanulta. Régi dicsöségünk. Meg hösvértöl pirosult. Na ne majrézzon. Kiterítik úgyis.

Visz a lábam mintha robot lennék. Megkerülöm a függönyt, kidugom a fejemet. Nézötér moraja. Skandalum, gondolom. Századok ültenek el sóhajtva köszöntlek arma virumque minden csak töredék foszlányok lógnék a szeren, de cserbenhagy az ékesszólás (sic) homorítson, súg a segéd, vágjon váteszi arcot. Hiába. Igaza volt: kiteritenek úgyis.

Hang az ajtó mögül. Fiam, ne fraternalizáljon a gyanúsitottakkal. Egy képet elölröl, egyet profilból. Aztán a nyilvántartóba vele.

Majd Kafka felügyelö úr foglalkozik az aktájával.

Ettöl azután úgy megrettentem, hogy fölébredtem. Sajnos ismét Önök elött állok; a belépöt nem téritik meg s Ond vezér unokája akós demizsonnal osztotta meg nászi ágyát. Mire kiérünk a müteremböl, eloszlott minden (nem úgy mint a buborék, mert az pattan [mint a ruhatetü]); a lég sem puszta, mert tele van szennyezö alakokkal, - izé, anyagokkal gusztustalan repülö tárgyakkal és izléstelen, fejreállt délibábbal. S az álomnak egyelöre nincs vége.. 